\title{
Strategies Applied by Pupils During the Representation of Natural Numbers
}

\author{
Šárka Pěchoučkováa - Martina Kašparováa \\ $a^{*}$ Department of Mathematics, Physics end technical Education, Faculty of Education, University of West \\ Bohemia in Plzeň, Klatovská 51, 30614 CZ
}

Received November 4, 2019; received in revised form November 18, 2019; accepted November 22, 2019

\begin{abstract}
The process of creating a conception of natural number poses a complex problem. We focused primarily on manipulation activities, namely on manipulation with Cuisenaire rods, and we studied the strategies employed by first-year and second-year pupils during the enactive representation of natural numbers $4,5,6,7,9,10,11$, $12,19,27,34,46$ and 55 . In the course of this experiment based on observation, following strategies were recorded: counting-on strategy, filling-in strategy " $\mathrm{L}$ ", filling-in strategy " $\mathrm{S}$ ", applied facts strategy, derived facts strategy, known facts strategy. The known facts strategy was most frequently applied in both first and second year and had two specific forms at older children. The use of counting-on strategy was considerably reduced in second grade. It was thus demonstrated that pupils had already automated operations of addition in the 0-20 range.
\end{abstract}

Keywords: natural number, manipulation, Cuisenaire rods, enactive representation, strategy

Classification: $97 \mathrm{C30}$

\section{Introduction}

Natural number, like all abstract terms, cannot be perceived through our senses. We only know that the number is deputized by its representants. Five stones represent the natural number "five" as well as five steps do. This count can be expressed by the word "five" in spoken or written language, both with letters or mathematical symbols.

In the first and second years, an experiment was conducted that focused on the different strategies that pupils use to represent some natural numbers. A total of 103 pupils participated in the experiment.

\section{Creating the conception of natural number}

The process of creating a conception of natural number has several phases. A stage that can be called "passive encounter with a number" commences soon after birth. A baby listens to adults' and siblings' speeches in its vicinity. In this speech, the number appears within the context of everyday situations. The child however perceives the number like he/he perceives other words, he-she might not be aware of them just yet and does not assign any meaning to the numeral. 
In the second year of life the "World of Numbers" emerges from the "World of Things". This stage is called "nuclei of numerical conceptions". Children begin to be aware of numbers and numerals in other people's speech. They realize that words three, five, eight go together and that their meaning is different from the meanings of other words (mum, dad, car, toy, ...). The rhythm plays an important role during the emerging of World of Numbers" from the "World of Things", i.e. use of simple (counting-out) rhymes.

In the stage of "creating the conception of quantity", a child does not use concrete numbers to express quantity but rather works with indeterminate quantity, expressed by words like many, few, too much,... The expression of quantity can however be influenced by child's subjective emotions. The number of objects that provoke positive emotions for a child (e.g. lollipops) will be labelled as few. The same number of objects that provoke negative emotions (e.g. toys to be tidied up) will be labelled many.

If the child is in the "stage of separated models", he/she understands "two" as e.g. pair organs: two, hands, two feet, two eyes, two ears. Later, he/she counts a larger number of objects by one, thus using numerals one, two, three... At the beginning however children recite a line of words without understanding the principle. This is manifested by omitting some words or changing their order. At about four years of age, the child begins to understand the connections between the recited line of words and counted objects - he/she points correctly at the objects one by one and recites a line of words (numerals). Each object is assigned a single correct numeral. Around five years of age, the child is capable of understanding the cardinality principle: the last pronounced word determines the total count of objects. Furthermore, he/she comprehends the order, i.e. that a number pronounced later is greater that a number pronounced before that. It is however necessary to underline that the conceptions of number are isolated in this phase; the child understand the single cases in a separated way. In fact, the child focuses on the object type, its color, size and position. From the child's point of view, 4 blue dice and 4 yellow dice represent two different situations. This phase is related to the preoperational stage of cognitive development.

The "first abstraction lift-up" occurs when the child starts to realize that when determining the count of objects, the only criterion that matters is their number and not color, size, type, position or material.

When the child realizes that 4 objects are all that is required for the conception of number 4 , he/she find themselves in the generic models stage and can work with different models fingers, abacus, towers of dice, number line, various types of natural number representation. This stage is related to the concrete operational stage, where it is important to perceive numbers visually, in particular by object manipulation or graphic representation. Children go through this stage at around 6/7 years of age.

The "second abstraction lift-up" occurs when the child has formed a concrete conception of a number and he/she find themselves at the abstraction level where he/she is able to work with the number without need to see concrete objects, thus working with the number only in their mind. The number can be replaced by symbols (e.g. letters). The child is at the formal operational stage. This stage begins at the onset of adolescence (Hejný 1990; Kaslová 2010).

\section{Representation and its types}


We understand representation as "basic element of cognitive relationship of a human to the world” (Kolláriková, Pupala 2001, p. 188). The Dictionary of Psychology (Hartl, Hartlová 2009, p. 506) defines representation in two ways:

1. "object itself, its conception or symbol that substitutes it"

2. "is understood by cognitivists as a direct stimulus, the elaboration of this stimulus in one's mind, its coding, its image, conception, abstract idea or alternatively recall of past experience"

External representation is that part of physical world that enables the pupil to penetrate deeper into the cultural world or to cultivate his/her spiritual world. Internal representation reproduces an image of the phenomenon in pupil's spiritual world, it is his new conception. It is the result of pupil's activity and it is impossible to induce it in the pupil's mind without their own interest (Hartl, Hartlová 2009).

In agreement with the above-mentioned definitions, we are going to distinguish external and internal representation of natural number in this text. A symbol substituting a natural number will be regarded as external representation. A conception of natural number will be regarded as internal (mental, cognitive) representation.

M. Sedláková (2004) speaks of external and internal (mental, cognitive) representation. She considers visual and verbal types of representation as external. Visual representation, mediated by an image or a drawing, is more concrete because it is associated to the visual modality of information only. The verbal (linguistic) representation, mediated by speech is abstract and it does not bear any direct connection to modality. Internal representation is further divided into symbolic and distributive representation.

When creating the concept of a number, the child works with various illustrative representants, which facilitate the formation of mental image and therefore also of internal representations of numbers (Hejný, Kuřina 2015). Auditory representation is also one of representation types. The beginning of a traditional Czech song "One, two, three, four, five" is and auditory representation of number 5 . There are various types of mental representation, ranging from separated models over generic models up to terms.

American psychologist Jerome Bruner distinguishes three types of representation alias three levels of cognition (Ruisel 2004):

- Enactive representation

- Iconic representation

- Symbolic representation

Enactive representation is directly connected to child's activity and physical experience. An example of number 4 enactive representation is the construction of a tower consisting of 4 blocks, four claps of hands, removal of four marbles from a bag or four jumps.

Cuisenaire rods are a suitable tool for the enactive representation of natural number. Their author was George Cuisenaire from Belgium (1891 - 1976), who claimed notes in musical scales corresponded to numeric relations. This is why he constructed a "mathematical keyboard", a set of carefully designed rods of specific lengths and colors. Cuisenaire rods have the shape of regular rectangular prism with the base edge of $1 \mathrm{~cm}$. The rod length varies 
between $1 \mathrm{~cm}$ and $10 \mathrm{~cm}$. Rods of equal length have the same color and represent the same number (in Table 1, in Fig. 1).

Table 1: Cuisenaire rods

\begin{tabular}{|l|l|l|l|}
\hline Rod length & Rod color & $\begin{array}{l}\text { Natural number } \\
\text { represented by the } \\
\text { rod }\end{array}$ & $\begin{array}{l}\text { Referred to as } \\
\text { further in this text }\end{array}$ \\
\hline $1 \mathrm{~cm}$ & White & 1 & Single-unit rod \\
\hline $2 \mathrm{~cm}$ & Red & 2 & Two-unit rod \\
\hline $3 \mathrm{~cm}$ & Light green & 3 & Three-unit rod \\
\hline $4 \mathrm{~cm}$ & Purple & 4 & Four-unit rod \\
\hline $5 \mathrm{~cm}$ & Yellow & 5 & Five-unit rod \\
\hline $6 \mathrm{~cm}$ & Dark green & 6 & Six-unit rod \\
\hline $7 \mathrm{~cm}$ & Black & 7 & Seven-unit rod \\
\hline $8 \mathrm{~cm}$ & Brown & 8 & Eight-unit rod \\
\hline $9 \mathrm{~cm}$ & Blue & 9 & Nine-unit rod \\
\hline $10 \mathrm{~cm}$ & orange & 10 & Ten-unit rod \\
\hline
\end{tabular}

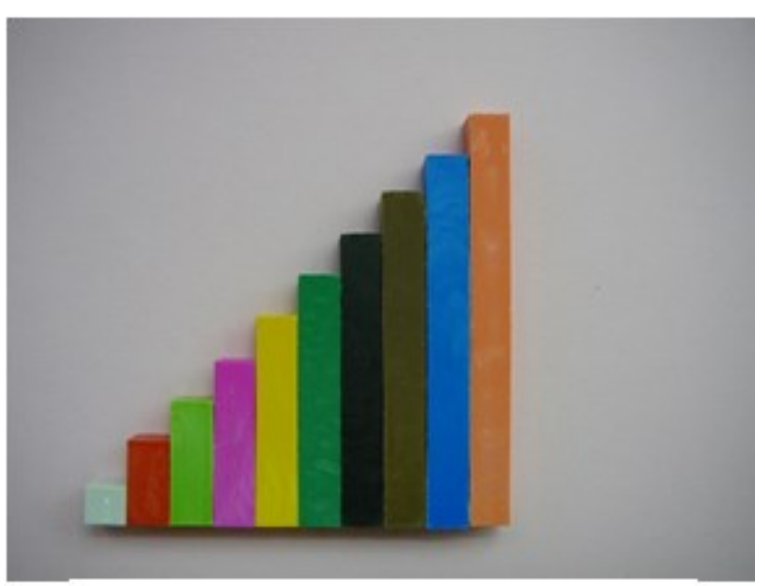

Fig. 1: Cuisenaire rods

Iconic representations encompass the use of various substitute models of reality such as images, schemes and concepts. Numeric figures of natural numbers $1-6$ on a die are an example of iconic representation (in Fig. 2). Kaslová (Kaslová, 2010) classifies these figures among natural number models and calls them "configuration models". 


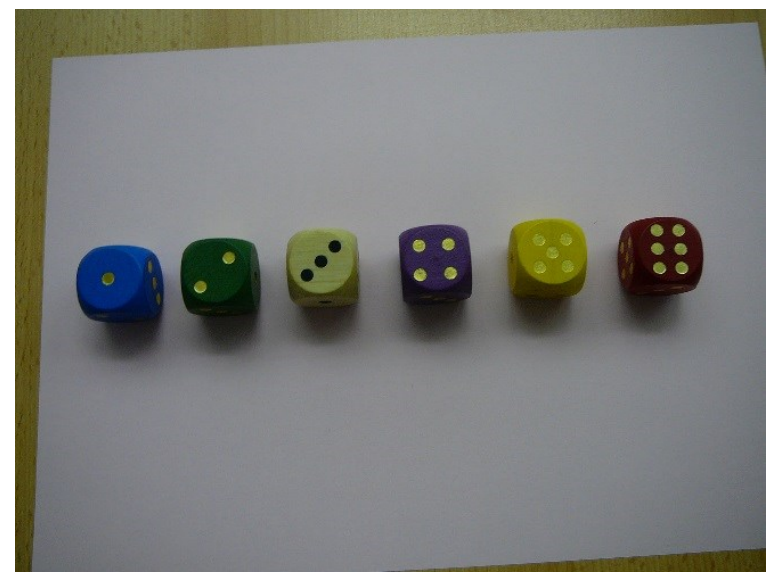

Fig. 2: Iconic representations of natural numbers on dice

Symbolic representations describe phenomena and relationships with language, e.g. using a mathematical symbolical language (mathematic symbols). " 4 " is a symbolic representation of number four. The use of symbolic representations means a deviation from imminent physical reality, it is therefore a representation mediated by abstract terms and categories.

\section{Experiment in the $1^{\text {st }}$ year of elementary school}

An experiment was carried out in the first year of elementary school, whose subject were the strategies used by pupils (6-7 years of age) during the manipulation with Cuisenaire rods. The aim was to discover, which strategies were applied by $1^{\text {st }}$ year pupils during the enactive representation of number 4 , number 5 , number 6 , number 9 and number 11 by the means of Cuisenaire rod manipulation. Our task was to select suitable tools for the enactive representation of a number and to build a series of activities to motivate children and simultaneously to discover their strategies applied during the enactive representation of above-mentioned numbers.

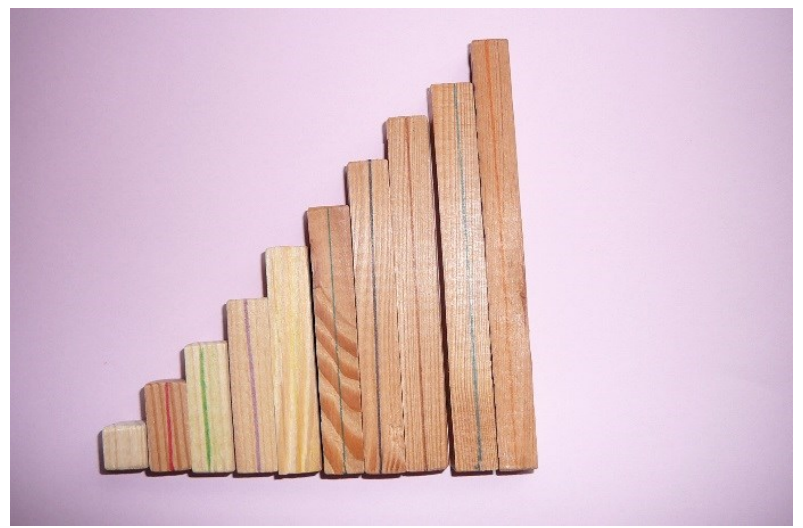

Fig. 3: Modified Cuisenaire rods

In the course of a whole school year, the pupils were presented with a total of 5 tasks, during which they used Cuisenaire rods so that the impact of pupils' fine motor skills on their manipulation activities was excluded. Modified rods were used in tasks 1, 2, 3, which differed from each other in length but not color to eliminate the color interference at children (in Fig. 3). In subsequent tasks, when children were already acquainted with this tool, and thus 
the impact of color on the rod choice was not fundamental, pupils worked with original Cuisenaire rods.

Every pupil was solving the tasks in an independent manner, separated from other children, sitting at a desk with piles of Cuisenaire rods to his/her disposition (in Table 2). Some piles were uncovered, others were revealed gradually during the problem solving. Near each pile, there was a card indicating the number represented by rods in the pile. Only at task 2 all rods were mixed and placed in a single pile. The tasks were motivated by the acquisition of "special money" represented by Cuisenaire rods. Before the actual task, children were introduced to the "value" of single "coins". The pupil was subsequently given a card representing the price of goods, and the pupil's task was to attempt to pay this price (to carry out and enactive representation of a natural number).

Table 2 shows the natural numbers in the order in which their enactive representation was required for each task, and Cuisenaire rods that the children could use.

Table 2: Overview of tasks for $1^{\text {st }}$ year students

\begin{tabular}{|c|c|c|c|c|c|}
\hline $\begin{array}{l}\text { Task } \\
\text { Date of } \\
\text { experiment }\end{array}$ & $\begin{array}{c}\text { Task } 1 \\
\text { November } \\
2014\end{array}$ & $\begin{array}{l}\text { Task } 2^{*} \\
\text { January } \\
2015\end{array}$ & $\begin{array}{c}\text { Task } 3 \\
\text { March } 2015\end{array}$ & $\begin{array}{c}\text { Task } 4 \\
\text { April } 2015\end{array}$ & $\begin{array}{c}\text { Task } 5 \\
\text { Juny } 2015\end{array}$ \\
\hline $\begin{array}{l}\text { Represented } \\
\text { numbers (in } \\
\text { this order) }\end{array}$ & $4,6,5$ & $4,6,5$ & $5,4,6$ & 4 & 4 \\
\hline $\begin{array}{l}\text { Used } \\
\text { Cuisenaire rods }\end{array}$ & \multicolumn{5}{|c|}{ Single-unit to three-unit rods } \\
\hline $\begin{array}{l}\text { Repesented } \\
\text { numbers (in } \\
\text { this order) }\end{array}$ & & & 9 & 6,5 & 6,5 \\
\hline $\begin{array}{l}\text { Used } \\
\text { Cuisenaire rods }\end{array}$ & & & $\begin{array}{l}\text { Single-unit } \\
\text { to six-unit } \\
\text { rods }\end{array}$ & \multicolumn{2}{|c|}{$\begin{array}{l}\text { Single-unit to four-unit } \\
\text { rods }\end{array}$} \\
\hline $\begin{array}{l}\text { Represented } \\
\text { numbers (in } \\
\text { this order) }\end{array}$ & & & & 11,9 & 11,9 \\
\hline $\begin{array}{l}\text { Used Cuisenare } \\
\text { rods }\end{array}$ & & & & \multicolumn{2}{|c|}{ Single-unit to six-unit rods } \\
\hline
\end{tabular}

\footnotetext{
${ }^{*}$ In Task 2, all the rods were in one pile.
} 




Fig. 4: Tools for first-year experiment

To illustrate how single tasks were presented to children, we describe here in detail the presentation of Task 1, which was motivated as follows. (If subsequent sentence begins on next line, it means that the child was given space for reaction). Occasional deviations tried to accommodate different children's personalities and their spontaneity.)

\section{Do you go shopping?}

\section{On your own or with mummy?}

What do you enjoy shopping the most?

Today we are going to play shopping together. We have some special money here. This is one Czech koruna (experimenter picks up a single-unit rod and shows it to the child), this is two Czech koruna (experimenter picks up a two-unit rod and shows it to the child), this is three Czech koruna (experimenter picks up a three-unit rod and shows it to the child). The goods' price is on these cards. Try to pay for it.

(In case the child does not react for a while, the experimenter reminds him/her of the "money values". If the child still doe not react, the experimenter suggests him/her the counting-on strategy.)

Subsequent tasks were presented in a similar way.

\section{Basic cognitive phenomena}

In the described experiment, children carried out an external representation of natural numbers, namely the enactive representation in agreement with Bruner. Some children counted out loud during the enactive representation. We named this phenomenon "verbal and auditory representation". There was thus an interconnection of the term "verbal" of psychologist Sedláková and the term "auditory" of didactics experts Hejný and Kuřina, as we assume both types of representation are closely related to each other, as are speech and hearing. One representation type is complemented by another one. The acoustic perception canal plays an important role here (Pěchoučková 2018).

Other phenomena linked to enactive representation of natural number using manipulation with Cuisenaire rods are visual perception of a number and haptic perception of a number. By perception we understand the sensory notion (Hartl, Hartlová 2009), i.e. the reflection of 
reality by sensory organs. By visual perception of a number, we intend auditory notion of a number, in particular the observation of objects before the beginning of actual representation of the given number. Taking the case of manipulation with Cuisenaire rods, the pupil carries out visual perception of e.g. number 2 if he spends time observing the pile of two-unit rods. This is why time was measured and recorded during the experiment. By haptic perception we intend the contact notion (in other words "tactile documentation of a number"), when the pupil touches objects with fingers or whole hand during or after the representation process, without manipulating them. In particular it means touching some of the Cuisenaire rods.

\section{Strategies used during the representation of a number}

The term "strategy" was introduced into didactics of mathematics by G. Polya. He understood a strategy as a plan for solving a problem. Vágnerová states that "strategy means establishing a certain process, which is deemed the most effective to reach the aim" (Vágnerová 2001, p. 75). Authors Hejný, Michalcová (2001) define strategy as a plan by which one puts into practice (or intends to put into practice) an activity that pursues a certain aim. This plan is not necessary detailed or thought-through. One can act spontaneously without realizing which strategy they are using. We are going to examine mathematical strategies, i.e. strategies linked to activities where mathematics is present. For simplification we are going to use here the term "strategy" only.

When examining the strategies used by pupils for the enactive representation of selected natural numbers, we proceeded from the research of Grey (1991), who discovered that the process of addition of two one-digit numbers $(4+3)$ without know context can involve

1. Method, when the pupil uses counting-on for each of the addends and subsequently also for the unified quantities

2. Method, where one quantity is known and the other is being counted on

3. Counting derived from known facts

4. Direct answer if the child already knows the links

The strategy chosen by child during the representation of a natural number can indicate the extent of child's understanding of this number (Gervasoni 1999). However, we have to consider that not always children use their strongest strategy. Therefore, it is necessary to prepare such situations for them that would lead to application of the most complex strategy.

Strategies described in following text were observed during the work with Cuisenaire rods. An illustration is attached for each strategy. Time required by pupil for described activity is stated in round brackets.

\section{Counting-on strategy}

The pupil carries out enactive representation of given number only by using single-unit rods, which he/she counts one by one. This strategy corresponds to process 1 described by Gray (see above).

\section{Illustration 1 - Adam}

Adam turns over card with number 5 . He counts five single-unit rods with his left hand and places them on the card (6 sec). 
Filling-in strategy „L“: Pupil chooses the largest rod to his/her disposition and thinks about additional rods to complete the first one (Pěchoučková 2018).

\section{Illustration 2 - Anna}

Anna turns over card with number 5. She picks up a three-unit rod with her right hand and places it on the table $(3 \mathrm{sec})$. She thinks, observed the piles with single-unit rods and two-unit rods $(3 \mathrm{sec})$. She adds two single-unit rods with her left hand.

During the enactive representation of number 5, Anna used the filling-in strategy „L“. She took the largest one of offered rods, i.e. a three-unit rod, and during a visual perception of number 1 and number 2 she thought which additional rod to use to complement the first one.

\section{Illustration 3 - Bruno}

Bruno turns over card with number 9. He picks up a six-unit rod with his right hand, says "Six." He lays the rod on the card $(3 \mathrm{sec})$. He observes the piles from right to left and stops at the three-unit rod pile (3 sec). He stretches his right hand out towards the pile, picks one rod, says "and three" an lays it on the card (3 sec).

During the enactive representation of number 9, Bruno used the filling-in strategy "L". He took the largest one of the offered rods - the six-unit one in this case - and based on visual perception of number 6 , number 5 , number 4 and number 3 he was considering which other rod to use to complement the first one.

Filling-in strategy „S“: Pupil chooses a smaller rod than the largest one from the offered set and thinks about additional rods to complete the first one (Pěchoučková 2018).

\section{Illustration 4 - Barbora}

Barbora turns over card with number 9. She picks up one five-unit rod with her right hand and puts it on the card $(3 \mathrm{sec}$ ). Her eyes wander between the piles of four-unit and five-unit rods (3 sec). Her eyes halt on the four-unit rod pile. She pick up one of them with her right hand and lays it on the card (2 sec).

During the enactive representation of number 9, Barbora used the filling-in strategy "S". She took a five-unit rod (which was not the largest one of the offered rods) and during a visual perception of number 4 and number 5 she was considering which other rod to use to complement the first one.

\section{Illustration 5 - Cyril}

Cyril turns over card with number 4. He picks up one single-unit rod with his left hand and put it on the table $(4 \mathrm{sec})$. He observes the rod piles $(5 \mathrm{sec})$. With the same hand, he takes one twounit rods and adds them to the single-unit rod $(2 \mathrm{sec})$. He stretches out his hand over the pile of two-unit rods, keeps it there and observed the pile $(2 \mathrm{sec})$. Then he moves his hand to the pile of single-unit rods, takes one of them and adds it to the two previous rods (1 sec). 
During the representation of number 4, Cyril first chose a single-unit rod, which was the smallest one of the offered rods. Then he carried out a visual perception of other numbers and thought about the choice of next rod.

Applied facts strategy: During the enactive representation of subsequent number, pupil exploits the representation of previous one (Pěchoučková 2018).

\section{Illustration 6 - Cilka}

Cilka turns over card with number 5. She looks at the pile with one-unit rods, then on the threeunit rod pile. She picks one three-unit rod with her right hand, holds it in the air, picks a twounit rod with her left had. She lays both rods simultaneously on the card (6 sec).

She turns over card with number 6. She looks at the three-unit rod pile. She picks one threeunit rod with her right hand and lays it on the card with number $(4 \mathrm{sec})$. She picks a two-unit rod with the same hand and lays it on the card again $(2 \mathrm{sec})$. She picks a single-unit rod with her left hand and adds it to the two rods laying on the card with number (2 sec).

During the representation of number 6 , Cilka used the applied facts strategy. The $3+2$ representation, which she applied in the previous task during the representation of number 5 , is part of $3+2+1$ representation of number 6 .

Derived facts strategy: During the enactive representation of given number, the pupil flexibly applies a suitable strategy of this number which he/she has memorised before, i.e. he/she have not applied it yet during previous manipulations (Pěchoučková 2018).

\section{Illustration 7 - Dana}

Dana turns over card with number 5. She counts two two-unit rods with her left hand, one by one, she picks both of them with her left hand and lays them on the card $(4 \mathrm{sec})$. Then she adds one single-unit rod with her left hand $(3 \mathrm{sec})$.

Dana applied the strategy of derived facts. She knows the $2+2$ addition and she derives the next number from this fact by the addition of 1 .

Illustration 8 - Daniel

Daniel turns over card with number 11. He says: "Eleven“. He picks one five-unit rod with his right hand, puts it on the card and says: "Five..." (4 sec). He picks another five-unit rod with the same hand, puts it on the card and says ,... and five..." $(2 \mathrm{sec})$. He pick a single-unit rod with his right hand, puts it on the card and says „....and one“ (2 sec).

Daniel used the strategy of derived facts. He uses the knowledge of two equal addends addition $(5+5)$ and he derived the next number from this addition by adding number 1 .

Known facts strategy: The pupil knows the appropriate numeric relation and performs the representation of given number based on the knowledge of this relation. This strategy corresponds to process 4 described by Gray (see text above).

Illustration 9 - Emil 
Emil reveals card with number 6. He picks a three-unit rod with his right hand, puts it on the card $(2 \mathrm{sec})$. He picks three single-unit rods at once with his left hand and adds them to the three-unit one (3 sec).

Emil used the known facts strategy. The time required for solving this problem corresponds to the applied strategy. Emil did not think about the solution as he did not observe the piles with rods during the task. He has already automated number 6 as $3+1+1+1$ in his mind.

Illustration 10 - Eva

Eva turns over card with number 11. She picks up one five-unit rod with her right hand and lays it on the card $(3 \mathrm{sec})$. She picks up a six-unit rod with her right hand and lays it on the card (2 sec).

Eva used the known facts strategy. She has had an automated relation of $5+6$.

Table 3 summarises the strategies applied for single numbers during the whole experiment. If we compare the strategy application frequency for single numbers, we can see that the known facts strategy was used with the lowest relative frequency at number 9 - pupils used other strategies for this number to a greater extent than for other numbers, e.g. filling-in strategy "L" or filling-in strategy " $\mathrm{S}$ ". Applied facts strategy was used exclusively for the representation of number 6 , although the order of tasks was chosen as to enable the use of this strategy also for the representation of number 5 , number 9 and number 11. Furthermore, the relative frequency of derived facts strategy use was low, this strategy appeared most frequently during the representation of number $11(5+5+1)$. Other numbers suitable for this strategy were number $5(2+2+1)$ and number $9(4+4+1)$. At number 9 , pupils mostly chose a five-unit rod first and worked with it based on known facts strategy or filling-in strategy „S“.

Table 3: Summary table $-1^{\text {st }}$ year

\begin{tabular}{|l|c|c|c|c|c|}
\hline & Number 4 & Number 5 & Number 6 & Number 9 & Number 11 \\
\hline Counting-on strategy & $20 \%$ & $20 \%$ & $21 \%$ & $10 \%$ & - \\
\hline Filling-in strategy „L“" & $5 \%$ & $9 \%$ & $10 \%$ & $18 \%$ & $23 \%$ \\
\hline Filling-in strategy „S“ & $2 \%$ & $1 \%$ & $9 \%$ & $28 \%$ & $16 \%$ \\
\hline Applied facts strategy & - & - & $6 \%$ & - & - \\
\hline Known facts strategy & $73 \%$ & $68 \%$ & $54 \%$ & $44 \%$ & $46 \%$ \\
\hline Derived facts strategy & - & $2 \%$ & - & - & $15 \%$ \\
\hline
\end{tabular}


The most frequently applied strategy overall was the known facts strategy, the least used one was applied facts strategy and the derived facts strategy. (Chart 1).

\section{Chart 1: Overview of strategies \\ in $1^{\text {st }}$ year}
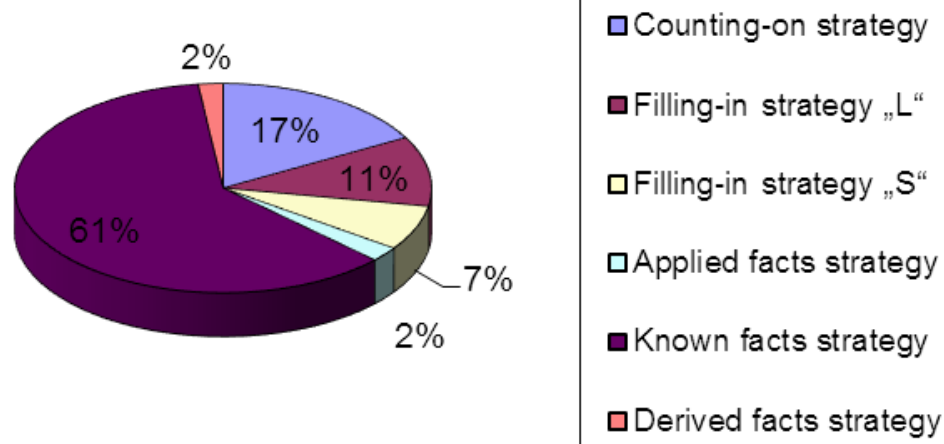

\section{Experiment in the $2^{\text {nd }}$ year of elementary school}

During the following school year, an experiment was carried out in the second year of elementary school with the same sample set of pupils $(7-8$ years old). The aim of this experiment was to discover which strategies were used by pupils during the manipulation of Cuisenaire rods for the enactive representation of number 7 , number 10 , number 12 , number 19 , number 27 , number 46 , number 34 and number 55 . The experimenters' task was again to select suitable tools for the enactive representation of a number and to compile a set of activities to motivate the children and simultaneously to enable the study of strategies used during the enactive representation of numbers above.

In the course of a whole school year, the pupils were presented by three problems for whose solution they used the original Cuisenaire rods.

Like in the $1^{\text {st }}$ year, the pupils were always elaborating the task in an independent manner, separated from other children in the class at a writing desk, where they had piles of Cuisenaire rods to their disposition. The rods were arranged left-to-right from single-unit ones to tenunit ones from the pupil's perspective (Table 4). Some piles were uncovered, others were revealed during the problem solution. There was a card at each pile stating which number is represented by the rods. The problems were again motivated by a purchase with help of "special money" represented by Cuisenaire rods. The pupils were given a large card representing the price of goods and their task was to try to pay for the goods (to perform an enactive representation of natural number) (Fig. 5). 


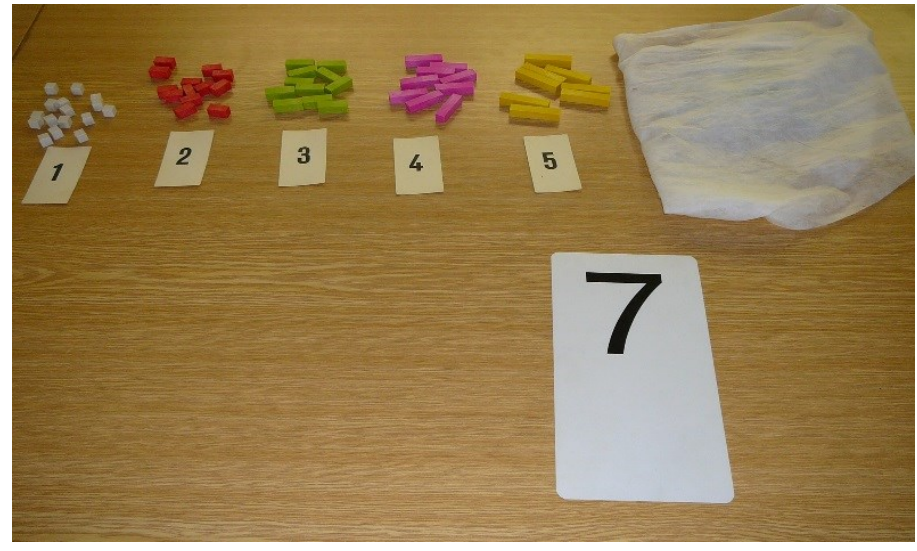

Fig. 5 Desk with tools prepared for 2nd year experiment

The pupils were asked to perform the enactive representation of eight numbers in the 1-100 category, where both odd and even numbers were represented. Table 4 contains information on the types of rods used by pupils for the enactive representation of given numbers. The script of information on used rods corresponds to the script of number(s) they were used for.

Table 4: Task overview for $2^{\text {nd }}$ year pupils

\begin{tabular}{|c|c|c|c|}
\hline $\begin{array}{l}\text { Task } \\
\text { Date of experiment }\end{array}$ & $\begin{array}{l}\text { Task } 1 \\
\text { November } 2015\end{array}$ & $\begin{array}{l}\text { Task } 2 \\
\text { February } 2016\end{array}$ & $\begin{array}{l}\text { Task } 3 \\
\text { May } 2016\end{array}$ \\
\hline Represented numbers & 7 & & \\
\hline Used Cuisenaire rods & $\begin{array}{l}\text { Single-unit to five- } \\
\text { unit rods }\end{array}$ & & \\
\hline Represented numbers & 10 & & \\
\hline Used Cuisenaire rods & $\begin{array}{l}\text { Single-unit to six- } \\
\text { unit rods }\end{array}$ & & \\
\hline Represented numbers & 12 & 12 & \\
\hline Used Cuisenaire rods & Single-unit to e & ght-unit rods & \\
\hline $\begin{array}{l}\text { Represented numbers (in this } \\
\text { order) }\end{array}$ & & $19,27,46$ & $27,46,34,55$ \\
\hline Used Cuisenaire rods & & \multicolumn{2}{|c|}{ Single-unit to ten-unit rods } \\
\hline
\end{tabular}

To illustrate how the single tasks were presented to children, we detail here the presentation of task 1 , which was motivated as follows:

Do you still remember our shopping together last year?

Do you remember what money we used?

Let's remind us again. 
This is one Czech koruna (experimenter picks up one single-unit rod from the pile and shows it to the child), this is two Czech koruna (experimenter picks up one two-unit rod from the pile and shows it to the child). This is three Czech koruna (experimenter picks up one three-unit rod from the pile and shows it to the child). Here we have four Czech koruna (experimenter picks up one four-unit rod from the pile and shows it to the child). This is five Czech koruna (experimenter picks up one five-unit rod from the pile and shows it to the child). The price of goods is on the card. Try to pay for it.

Now I am going to add you some more money (experimenter reveals another pile with rods). Here we have six Czech koruna (experimenter picks up one six-unit rod from the pile and shows it to the child). The price of goods is on the card. Try to pay for it.

We are going to add some more money again (experimenter reveals other piles with rods). Here we have seven Czech koruna (experimenter picks up one seven-unit rod from the pile and shows it to the child) and here are eight Czech koruna (experimenter picks up one eightunit rod from the pile and shows it to the child). The price of goods is on the card. Try to pay for it.

Only some of the strategies applies by pupils in the $1^{\text {st }}$ year were observed again in the $2^{\text {nd }}$ year during the enactive representation of natural numbers $7,10,12,19,27,34,46$ and 55 using the Cuisenaire rods. These were the counting-on strategy, the filling-in strategy " $\mathrm{L}$ ", the filling-in strategy " $\mathrm{S}$ ", the applied facts strategy and the known facts strategy. As these strategies were described in detail in previous text, their description will not be repeated here but we are going to demonstrate each of them on a concrete illustration. We will focus on the last one, known facts strategy, whose use had in the case of enactive representation of natural numbers two specific forms depending on the procedure applied by the pupil.

\section{Counting-on strategy:}

\section{Illustration 11 - Filip}

Filip turns over card with number 7. He looks in turns on the card with number and on uncovered piles with rods. He hovers his hand over four-unit and three-unit rods. He keeps his right hand over the pile of three-unit rods. He looks also on other piles and hesitates (10 sec). Eventually, he picks seven single-unit rods with hss right hand $(10 \mathrm{sec})$ and lays them one by one near the card $(12 \mathrm{sec})$.

Before starting to carry out the enactive representation of number 7, Filip performed visual perception of all rods to his disposition to gain insight into the problem. In the meantime, he was thinking which strategy to choose. Eventually he decided in favour of counting-on strategy.

\section{Filling-in strategy " $\mathrm{L}$ ":}

\section{Illustration 12 - Ferdinand}

Ferdinand turns over card with number 55. He counts five ten-unit rods with the thumb of his right hand, picks them with his right hand and transfers immediately to his left hand (8 sec). 
He double-checks number 55 on the card, looks at the piles and thinks (6 sec). He picks five single-unit rods with his right hand, one by one. He puts the ten-unit rods on the table near the card, counts again the single-unit rods in his hands and then adds them to the card with number $(12 \mathrm{sec})$.

During the enactive representation of number 55 , Ferdinand used the filling in strategy " $\mathrm{L}$ " (10 $+10+10+10+10+1+1+1+1+1)$. First, he chose the largest of available rods - ten-unit rods - and then he thought which other rods to use to complete them. He was using the visual perception of all available rods and the auditory perception of single rods as aid.

\section{Filling-in strategy "S":}

\section{Illustration 13 - Gabriela}

Gabriela turns over card with number 7, looks at it, observes the available piles with rods, looks at the experimenter. She rubs her lips with her left hand, keeps watching the card. (Experimenter tries to repeat the task: "Try to pay for this.") She observed the rod piles again (25 sec). She picks three three-unit rods at the same time with her left hand, lays the hand with rods on the card (7 sec) and asks: "Here?" (Experimenter repeats: "Seven Czech koruna.") Gabriela puts rods on the table, she touches two four-unit rods, she pauses. She goes back to three-unit rods laying on the table, puts her left hand on them and counts. She raises her head smiling and says: "A-ha." (6 sec). She puts one three-unit rod back on the pile, pick one singleunit rod with the same hand and observes the experimenter's reaction (the experimenter invites Gabriela to lay the rods on the card). She moves chosen rods on the card with her right hand (8 sec).

Before beginning the enactive representation of number 7, Gabriela performed a visual perception of all offered rods to gain insight into the problem. The enactive representation of this number was also supported by a haptic perception of four-unit rods. She used the fillingin strategy "S" $(3+3+3)$, where she made a mistake. Nevertheless, she realized this mistake and replaced one three-unit rod by a single-unit one $(3+3+1)$.

\section{Applied facts strategy:}

\section{Illustration 14 - Gustav}

Gustav turns over card with number 7. He picks a three-unit rod with his left hand, lays it on the card. He picks a four-unit rod with he same hand and lays it on the card $(7 \mathrm{sec})$.

He turns over card with numbers 10. He picks one three-unit rod with his left hand and one four-unit rod with his right hand at the same time and lays both rods simultaneously on the card. He picks one more three-unit rod with his left hand and adds it to the previous two rods (8 sec).

Gustav employed the applied facts strategy during the representation of number 10 . The $3+$ 4 representation used by him in the previous task with number 7 was part of his $3+4+3$ representation of number 10 . The use of this strategy is a proof of boy's insight into number 10. 


\section{Known facts strategy:}

In the case of this strategy, two specific forms emerged. The first form corresponded to the known facts strategy applied by pupils in the first year. The pupil has an automated relation that uses the addition of natural number and performs the enactive representation of given number based on this relation.

\section{Illustration 15 - Hana}

Hana turns over card with number 27. She chooses two ten-unit rods, which she picks with her right hand, and lays them on the table. She successively takes one six-unit rod and one singleunit rod and moves all rods towards the card $(8 \mathrm{sec})$.

During the enactive representation of number 27, Hana employed the known facts strategy $(10+10+6+1)$

The other specific form of known facts strategy was based on using the procedure of expanded natural number notation in decimal numeral system.

\section{Illustration 16 - Ivan}

Ivan turns over card with number 27. He picks one ten-unit rod with her right hand and transfers it in his left hand. He picks another ten-unit rod in the same manner. With his free hand, he picks one seven-unit rod and aligns all rods near the card (10 sec).

During the enactive representation of number 27 , Ivan used the known facts strategy $(10+10$ +7 ), He thus used a procedure of expanded natural number notation in decimal system.

\section{Illustration 17 - Irena}

Irena turns over card with number 55. She counts five ten-unit rods one by one with both hands and holds them in her left hand. She picks a five-unit rod with her right hand. She lays all rods one by one near the card $(24 \mathrm{sec})$.

During the enactive representation of number 55 , Irena used the known facts strategy $(10+$ $10+10+10+10+5$ ). She understood number 55 as a procept. She used the procedure of expanded natural number notation in decimal system.

Table 5: Summary table $-2^{\text {nd }}$ year

\begin{tabular}{|l|l|l|l|l|l|l|l|l|}
\hline & $\begin{array}{l}\text { Number } \\
7\end{array}$ & $\begin{array}{l}\text { Number } \\
10\end{array}$ & $\begin{array}{l}\text { Number } \\
12\end{array}$ & $\begin{array}{l}\text { Number } \\
19\end{array}$ & $\begin{array}{l}\text { Number } \\
27\end{array}$ & $\begin{array}{l}\text { Number } \\
46\end{array}$ & $\begin{array}{l}\text { Number } \\
34\end{array}$ & $\begin{array}{l}\text { Number } \\
55\end{array}$ \\
\hline Strategy & $15 \%$ & & & & & & & \\
\hline Filling-in & & & & & & & & \\
strategy „L“ & & & & & & & & \\
\hline
\end{tabular}




\begin{tabular}{|c|c|c|c|c|c|c|c|c|}
\hline $\begin{array}{l}\text { Filling-in } \\
\text { strategy „S“ }\end{array}$ & $14 \%$ & & & & & & $27 \%$ & \\
\hline $\begin{array}{l}\text { Applied facts } \\
\text { strategy }\end{array}$ & & $6 \%$ & $9 \%$ & & & & & \\
\hline $\begin{array}{l}\text { Known facts } \\
\text { strategy }\end{array}$ & $71 \%$ & $94 \%$ & $91 \%$ & $\begin{array}{l}100 \% \\
37 \% \\
63 \%\end{array}$ & $\begin{array}{l}100 \% \\
41 \% \\
59 \%\end{array}$ & $\begin{array}{l}100 \% \\
39 \% \\
61 \%\end{array}$ & $\begin{array}{l}73 \% \\
21 \% \\
52 \%\end{array}$ & $\begin{array}{l}92 \% \\
21 \% \\
71 \%\end{array}$ \\
\hline
\end{tabular}

Table 5 summarizes the strategies employed for single numbers during the experiment. When comparing the frequencies of strategies used for every number, we can see that then known facts strategy was used by pupils at all of them. It was $86 \%$ of all cases (Chart 2). During the enactive representation of number 19, number 27 and number 46, this strategy was used by all pupils from the sample set. Most of them linked this strategy to the method of expanded two-digit number notation in decimal system. This was the case for $63 \%$ of pupils at number 19, $59 \%$ pupils at number 27 and $61 \%$ of pupils at number 46 . This could be related to the fact that during that time of school year, pupils have been already working with decomposition of two-digit numbers into tens and ones. On the other hand, the known facts strategy is not the only strategy employed for number 12 . The used facts strategy was employed here as well, where pupils exploited the enactive representation of previous number 10 . The same strategy occurred at number 10 , where pupils used the representation of number 7 . The application of this strategy would be too lengthy for other numbers, though. The enactive representation of number 55 corresponded to two strategies. The known facts strategy prevailed but the filling-in strategy "L" was present as well (Chart 2).

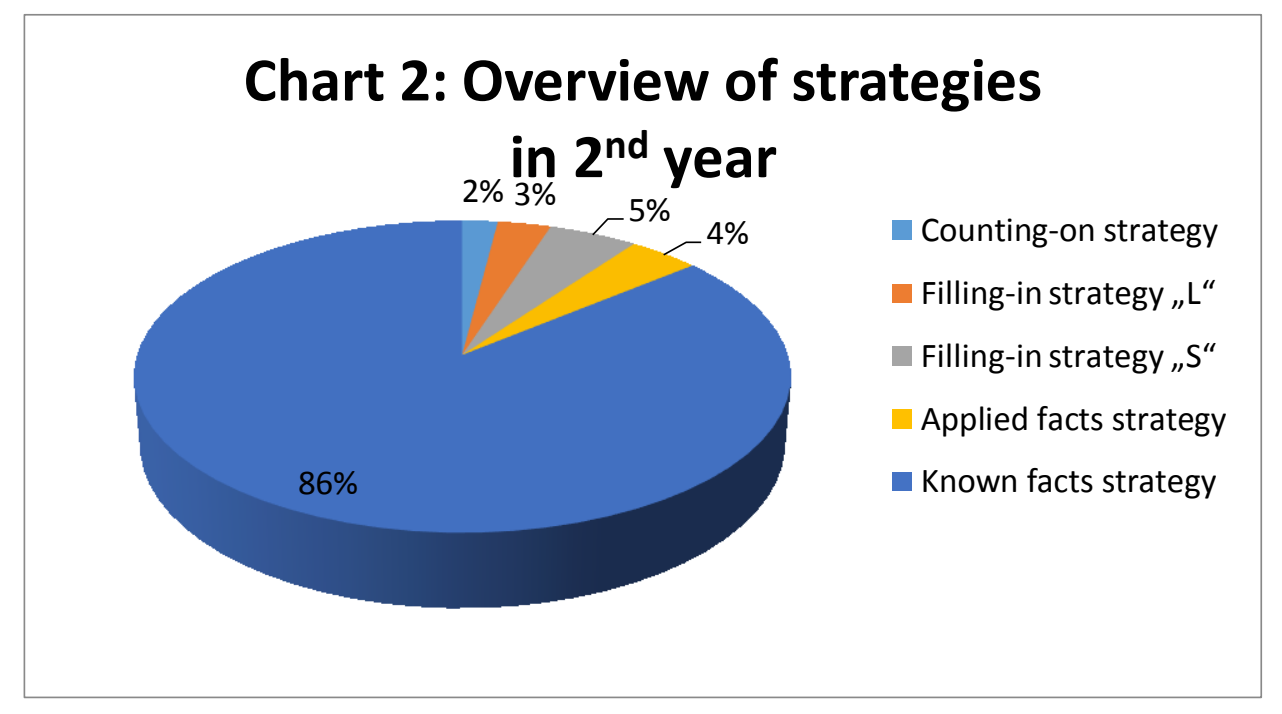


The known facts strategy was the most frequently used one, the counting-on strategy was used the least (Chart 2). The reason for most frequent use of known facts strategy could have been that pupils had already automated numeric relations of addition in the 1-20 range as well as the decomposition of a two-digit number into tens and ones.

When we compare strategies used by pupils in the first year during the enactive representation of numbers above with strategies used in the second year, we can say that the known facts strategy was the most frequently used strategy in both years, although its use increased by more than a third in the second year. This was presumably caused by the fact that the second-year pupils had already automated numeric relations of addition in the 1-20 range. Also, this strategy was suitable for the extended natural number notation in decimal system. The application of counting-on strategy was considerably reduced in second year for all numbers including single-digit ones; use of this strategy would be too lengthy for two-digit numbers. The derived facts strategy was observed to a small extent in the first year however it did not occur again in the second year. The applied facts strategy was a minority strategy in both years.

\section{Conclusion}

The process of natural number conception formation is accompanied by various phenomena. Here we focussed on strategies employed by pupils for the enactive representation of selected natural numbers using manipulation with Cuisenaire rods. The experiment however followed also other interesting phenomena, such as the process of forming separated and generic models of given natural number as well as processual, conceptual and proceptual understanding of a number and numeric relations used by pupils during the enactive representation of a number. The analysis of these phenomena will be undertaken later.

\section{Acknowledgement}

The article is a partial output of the project GRAK2019 of the Faculty of Education of the University of West Bohemia in Pilsen.

\section{References}

Gervasoni, A., 1999. Children Learning Number. In Proceedings of Targeting Excellence. Continuing the Journey. Melbourne: Education Victoria, pp. 20 - 24. ISSN 1326-0286.

Gray, E. M.; Tall, D. O., 1991. Duality, Ambiguity and Flexibility in Successful Mathematical Thinking. In Proceedings of PME XIII. Assisi: Education, pp. 72 - 79. ISBN 978-0-86491-366-1, ISSN 0771-100X.

Hartl, P.; Hartlová, H., 2009. Psychologický slovník. 2. vyd. Praha: Portál. 774 s. ISBN 978-80-7367-569-1.

Hejný, M., 1990. Teória vyučovania matematiky 2. 1. vyd. Bratislava: SPN. 554 s. ISBN 80-08-00014-7.

Hejný, M.; Kuřina, F., 2015. Dítě, škola a matematika. Konstruktivistické př́stupy k vyučování. 3. vyd. Praha: Portál. 232 s. ISBN 80-7178-581-4.

Hejný, M.; Michalcová, A., 2001. Skúmanie matematického riesitelského postupu. 1. vyd. Bratislava: Metodické centrum. 216 s. ISBN 80-8052-085-2.

Kaslová, M., 2010. Předmatematické činnosti v předškolním vzdělávání. 1. vyd. Praha: Raabe. 206 s. ISBN 978-8086307-96-1.

Kolláriková, Z.; Pupala, B. a kol., 2001. Předškolní a primární pedagogika. 1. vyd. Praha: Portal. 455 s. ISBN $80-$ 7178-585-7. 
Pěchoučková, Š. 2018. Přrirozené čílo a manipulace s Cuisenairovými hranolky. 1. vyd. Plzeň: Západočeská univerzita v Plzni. 118 s. ISBN 978-80-261-0765-1.

Ruisel, I., 2004. Inteligence a myšlení. 1. vyd. Bratislava: Ikar. 192 s. ISBN 80-7178-425-7.

Sedláková, M., 2004. Vybrané kapitoly z kognitivní psychologie. Mentální reprezentace, mentální modely. 1. vyd. Praha: Grada Publishing, a. s. 252 s. ISBN 80-247-0375-0.

Vágnerová, M., 2001. Kognitivní a sociální psychologie žáka základní školy. 1. vyd. Praha: Nakladatelství Karolinum, Univerzita Karlova v Praze. 304 s. ISBN 80-246-0181-8. 